\title{
ANTIOXIDATIVE AND ANTIBACTERIAL POTENTIALS OF FUNGAL ENDOPHYTES FROM JUSTICIA WYNAADENSIS HEYNE: AN ETHNOMEDICINAL RAIN FOREST SPECIES OF WESTERN GHATS
}

\author{
MADHUCHHANDA DAS ${ }^{1}$, HARISCHANDRA SRIPATHY PRAKASH ${ }^{2}$, MONNANDA SOMAIAH NALINI ${ }^{1 *}$ \\ ${ }^{1}$ Department of Studies in Botany, University of Mysore, Manasagangotri, Mysore - 570 006, Karnataka, India. ${ }^{2}$ Department of Studies in \\ Biotechnology, University of Mysore, Manasagangotri, Mysore - 570 006, Karnataka, India. Email: nmsomaiah@gmail.com
}

Received: 23 February 2017, Revised and Accepted: 16 March 2017

\section{ABSTRACT}

Objective: Endophytes, living within the medicinal plants, are recognized as an alternative source of bioactive components useful for human health. This study aims to isolate and identify the fungal endophytes from the ethnomedicinal rain forest plant Justicia wynaadensis and evaluation of their antioxidant and antimicrobial potentials.

Methods: Endophytic fungi were isolated and identified by sequencing the internal transcribed spacer. The secondary metabolites were extracted with ethyl acetate and evaluated for the total phenolic, flavonoid, antioxidant, and antibacterial potentials. The antioxidative capacities were determined using different experimental models, viz, radical scavenging capacity, reducing power, and inhibition of lipid peroxidation. The antibacterial potential of extracts was determined through disc diffusion method and by evaluating minimum inhibitory concentration through microplate technique.

Results: A total of nine fungal endophytes belonging to six genera were identified. The total phenolic content of the extracts ranged from $4.8 \pm 0.08$ to $20.74 \pm 0.96 \mathrm{mg}$ Gallic acid equivalent/g dry extract. Flavonoid was present in eight extracts in the range of $2.1 \pm 0.08$ to $8.75 \pm 0.6 \mathrm{mg}$ catechin equivalent/g dry extract. Fusarium incarnatum was found to have potentially high antioxidant capacity as well as broad spectrum antibacterial activity against Gram-positive and Gram-negative bacteria.

Conclusion: This study reported various endophytic fungi from the plant $J$. wynaadensis. This is the first attempt to explore the treasure of endophytes and their bioactive potentiality from this plant. Hence, our findings encourage the exploration of these fungi and exploit them in search of potential drug discovery.

Keywords: Endophytic fungi, Justicia wynaadensis, Western Ghats, Antioxidant, Antibacterial, Fusarium incarnatum.

(c) 2017 The Authors. Published by Innovare Academic Sciences Pvt Ltd. This is an open access article under the CC BY license (http://creativecommons. org/licenses/by/4. 0/) DOI: http://dx.doi.org/10.22159/ajpcr.2017.v10i6.18106

\section{INTRODUCTION}

The importance of medicinal plants as a source of medicine is as old as the civilization. Natural products have been exploited for human use for thousands of years and plants have been the chief source of compounds used for medicine. Around $80 \%$ of the world population uses the beneficial effects of the natural compounds of medicinal plants for health care in some form or the other [1]. Medicinal plants have been exploited rigorously to obtain the natural compounds and as a result, the natural reservoir is facing the threats of extinction.

In recent years, microorganisms have been recognized as rich sources of biologically active metabolites that finds wide-ranging exploitation in medicine, agriculture, and industry [2]. Plants may serve as a reservoir of large numbers of microorganisms known as endophytes that live within plant tissues for all or part of their life cycle and cause no apparent infections [3]. Endophytes are chemical synthesizers inside plants [4], in other words, they play a role as a selection system for microbes to produce bioactive substances with low toxicity towards higher organisms [5]. Bioactive natural compounds produced by endophytes have been promising in terms of safety and human health concerns [6].

Microorganisms and humans have developed resistance to the existing antibiotics posing needs of newer therapeutic agents. The fungal endophyte derived bioactive compounds provide us with new choices of novel antibiotic with which can be effectively used against infectious diseases. Endophytes provide a broad variety of bioactive secondary metabolites with a unique structure, including alkaloids, benzopyranones, quinones, flavonoids, phenolic acids, steroids, terpenoids, tetralones, xanthones, and others [7]. Such bioactive metabolites find wide-ranging application as agrochemicals, antibiotics, immune-suppressants, antiparasitics, antioxidants, and anticancer agents [8].

Antioxidant among plethora of substances is an important compound and potential therapeutic agent against the oxidative damage. Oxidative damage to cell component plays vital role in many human diseases, viz., cancer, Alzheimer's disease, and kidney disease. Antioxidant compounds can be thiols, ascorbic acids (AAs), or polyphenols. Phenolic acids and flavonoids are major bioactive components isolated from endophytic fungi [9-11]

Justicia wynaadensis Heyne is an endemic plant, naturally occurring in the rain forest of Western Ghats, East Nilgiris, and South Malabar Hills in South India [12]. The plant is locally known as "Madubana soppu" or "Maddhu thoppu," belongs to the family Acanthaceae. The family Acanthaceae consists of 250 genera, many of which have ethnomedicinal properties [13]. J. wynaadensis also has ethnomedicinal properties. The juice of the stem and leaf of this plant is used locally to cure asthma, boost immunity, as anthelmintic, and antidiabetic [14]. J. wynaadensis also has cholesterol lowering properties [15]. The stem and leaf juice of this plant is extracted in boiling water. A deep purple colored extract obtained through this process is consumed as it is or as a sweet dish by the local community. This traditional practice is believed to offer wellness throughout the year. Although the endemic plant is ethnomedicinal, no reports are available on its endophytic profile. 
Therefore, the primary aim of the study was to isolate, identify the fungal endophytes morphologically as well as with the help of molecular tools from the ethnomedicinal plant J. wynaadensis and the evaluation of antioxidant and antimicrobial activity of the endophytic fungal isolates.

\section{METHODS}

Chemicals

Gallic acid, trolox, AA, 2, 2'-azino-bis(3- ethylbenzthiazoline-6sulphonic acid) (ABTS), and 1, 1-diphenyl-2- picrylhydrazyl (DPPH) were purchased from Sigma-Aldrich (St. Louis, MO, USA). FolinCiocalteu's reagent was purchased from SRL Pvt. Ltd. (Mumbai, India). Sodium hypochlorite, potassium ferricyanide, trichloroacetic acid (TCA), ferric chloride, sodium nitrite, aluminum chloride, potassium persulfate, thiobarbituric acid (TBA), and sodium dodecyl sulfate (SDS) and all other general chemicals and solvents were of analytical grade. Triple distilled water was used wherever necessary. Antibiotic discs and Mueller-Hinton medium were purchased from Hi Media (Mumbai, India).

\section{Collection of the plant material}

J. wynaadensis was collected from the Talacauvery sub-cluster $\left(012^{\circ} 17^{\prime}\right.$ to $012^{\circ} 27^{\prime} \mathrm{N}$ and $075^{\circ} 26^{\prime}$ to $075^{\circ} 33^{\prime} \mathrm{E}$ ) of the Western Ghats, in Kodagu district, Karnataka state, India, during August 2012 (Fig. 1). The plant parts such as stems and leaves were collected in zip lock polyethylene bags and brought to the laboratory and processed for the isolation within $24 \mathrm{hrs}$ of collection. A herbarium specimen has been preserved in the Department of Studies in Botany, University of Mysore.

\section{Isolation of endophytic fungi from the plant parts}

Endophytic fungal isolation was carried out under aseptic conditions, according to Tejesvi et al. [16]. The plant parts were surface sterilized with ethanol (70\%, 1 minute), sodium hypochlorite (3.5\%, 3 minutes) and then washed 3-4 times in sterile distilled water. The dried plant parts were cut into $1.0 \mathrm{~cm} \times 0.1 \mathrm{~cm} \times 0.1 \mathrm{~cm}$ pieces and 400 plant fragments were placed on water agar media $(2 \%, \mathrm{w} / \mathrm{v})$ for the isolation of endophytic fungi, supplemented with the antibiotic streptomycin $(50 \mathrm{mg} / \mathrm{L})$ to inhibit bacterial growth. The effectiveness of the surface sterilization was confirmed [17]. The plates were sealed with Clingwrap ${ }^{\mathrm{TM}}$ and incubated at $28 \pm 2^{\circ} \mathrm{C}$ with $12 \mathrm{hrs}$ of light and dark cycles for 4-6 weeks. The fungal hyphae that emerged on the fragments (Fig. 2) were further inoculated onto potato dextrose agar slants and incubated at $28 \pm 2^{\circ} \mathrm{C}$ for $10-15$ days and maintained as pure cultures at $4^{\circ} \mathrm{C}$ for further use.

\section{Identification of the fungal endophytes}

Microscopic slides of each endophyte were prepared using lactophenol cotton blue stain (Hi Media, Mumbai, India). The slides were examined under the light microscope (Labovision, India) for morphological analysis. Based on the cultural characteristics and spore structure, nine endophytic fungi were selected for the molecular identification and further analysis of their metabolites.

\section{Molecular identification of fungal endophytes}

Actively grown mycelial plugs from nine morphologically different endophytic fungi were inoculated into potato dextrose broth (PDB, Hi Media, Mumbai, India). The isolates were grown in still culture at $28 \pm 2{ }^{\circ} \mathrm{C}$ for $7-10$ days. The genomic DNA was extracted from the freezedried fungal mats by cetyltrimethylammonium bromide method with slight modifications [18]. The DNA concentration was estimated by measuring the absorbance at 260 and $280 \mathrm{~nm}$ (Thermo Scientific Nanodrop 2000/2000c, Bengaluru, India). Target regions of the rDNA internal transcribed spacer (ITS) 1 and 2 regions and 5.8 rRNA genes were amplified using primers ITS 1 and ITS 4. The amplification was performed in a total reaction volume of $25 \mu \mathrm{l}$ containing $200 \mu \mathrm{mol} / \mathrm{L}$ deoxynucleotide triphosphates, $10 \mathrm{pmol} / \mu \mathrm{l}$ of each primer and $50 \mathrm{ng}$ template DNA. The amplification conditions consisted of an initial denaturation step at $95^{\circ} \mathrm{C}$ for 3 minutes, followed by 35 cycles of $92^{\circ} \mathrm{C}$ for 1 minute, $50^{\circ} \mathrm{C}$ for 1 minute, $72^{\circ} \mathrm{C}$ for 2 minutes, and a final extension at $72^{\circ} \mathrm{C}$ for 10 minutes. The amplified product was subjected

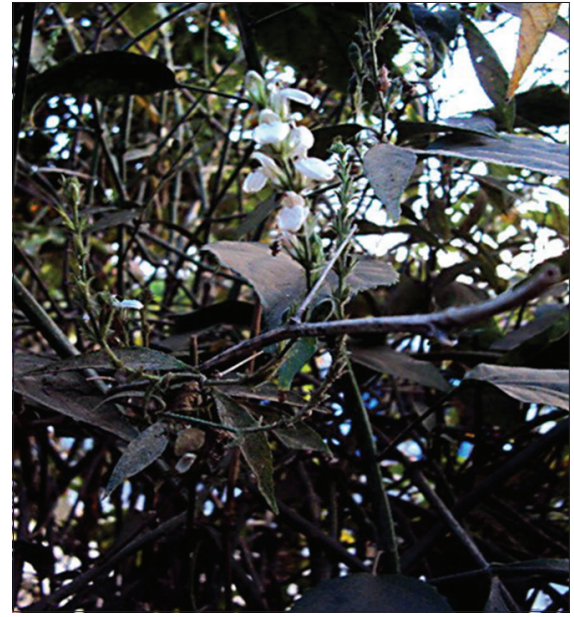

Fig. 1: Justicia wynaadensis Heyne., collected from the natura habitat of the Western Ghats

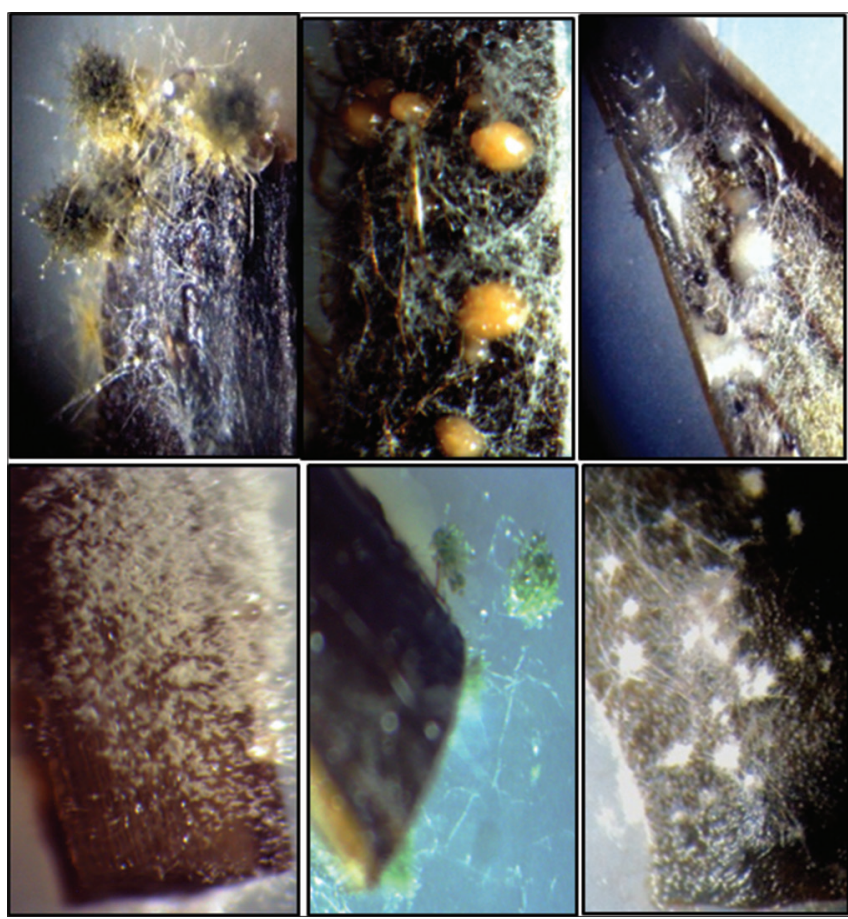

Fig. 2: Emergence of fungal hyphae from plant fragments plated on agar media

to sequencing at Chromous Biotech Pvt. Ltd. Bengaluru, India. The endophyte sequences were aligned with the reference sequences using the BLAST algorithm and submitted to the NCBI GenBank nucleotide collection.

\section{Fermentation and extraction of metabolites}

The pure cultures of 10-day-old isolates were inoculated into $500 \mathrm{ml}$ of PDB contained in Erlenmeyer flasks in duplicates and kept for incubation for 3 weeks at $28 \pm 2{ }^{\circ} \mathrm{C}$. The fermentation broth of each endophyte was extracted with ethyl acetate thrice at room temperature and further concentrated by a Rotary flash evaporator (Superfit Model, PBU-6D, India). The residue obtained was designated as the crude dry extract and stored in glass vials, until use.

Determination of the total phenolic content (TPC)

The TPC was assessed according to the Folin-Ciocalteau (FC) method of Liu et al. with some modifications [19]. $1 \mathrm{ml}$ of FC reagent and $2 \mathrm{ml}$ of 
sodium carbonate $(20 \%, \mathrm{w} / \mathrm{v})$ was mixed with the crude extracts. The mixture was incubated for 45 minutes in the dark. The absorbance was read at $765 \mathrm{~nm}$ (T-60, TTL Technology, India). The TPC of the extracts was expressed as mg of Gallic acid equivalent (GAE)/g of the extract.

\section{Determination of total flavonoid content (TFC)}

The total flavonoid was determined according to the method of Barros et al. [20]. The fungal extract was mixed with sodium nitrite $(5 \%, 75 \mu \mathrm{l})$. After 5 minutes aluminum chloride $(10 \%, 150 \mu \mathrm{l})$ and sodium hydroxide $(1 \mathrm{M}, 500 \mu \mathrm{l})$ were added. The absorbance was measured at $510 \mathrm{~nm}$. The content of flavonoid was calculated using calibration curve of catechin, and the results were expressed as mg of catechin equivalent (CE)/g of the extract.

\section{Determination of antioxidant capacity}

ABTS ${ }^{+}$radical scavenging assay

The $\mathrm{ABTS}^{+}$scavenging capacity was determined by the method of Re et al. [21]. ABTS $^{+}$was generated by the mixing of ABTS $(7 \mathrm{mM})$ and potassium persulfate $(2.45 \mathrm{mM})$. The working solution was prepared by diluting with methanol to obtain an absorbance of 0.70 at $734 \mathrm{~nm}$. The activity was expressed as Trolox equivalent antioxidant capacity (mg TE/g dry extract).

\section{DPPH radical scavenging assay}

The quenching ability of DPPH was measured according to the procedure of Liu et al. with modifications [19]. A methanolic solution of DPPH $(0.001 \mathrm{mM})$ was added to the fungal extract. The absorbance was read at $517 \mathrm{~nm}$ after 20 minutes of incubation. The scavenging activity was expressed as inhibitory concentration $50 \%\left(\mathrm{IC}_{50}\right)(\mu \mathrm{g} / \mathrm{ml})$. AA was used as the standard. The scavenging ability of the DPPH radical was calculated by the formula:

$$
\% \text { Scavenging }=\frac{\mathrm{A}_{\text {control }}-\mathrm{A}_{\text {sample }}}{\mathrm{A}_{\text {control }}} \times 100
$$

\section{Reducing power assay}

The reducing power was measured by the method of Oyaizu with modifications [22]. The fungal extracts were mixed with phosphate buffer $(0.2 \mathrm{M}, \mathrm{pH} 6.5)$ and potassium ferricyanide $(1 \%, 0.5 \mathrm{ml})$. The mixture was then incubated at $50^{\circ} \mathrm{C}$ for 20 minutes. After incubation, TCA $(10 \% \mathrm{w} / \mathrm{v}, 0.5 \mathrm{ml})$ was added and centrifuged at $3000 \mathrm{rpm}$ for 10 minutes. To the supernatant, the same volume of distilled water and ferric chloride $(0.1 \%, 300 \mu \mathrm{l})$ was added, and the absorbance was measured at $700 \mathrm{~nm}$. The activity was expressed as $\mathrm{mg} \mathrm{AA} / \mathrm{g}$ dry extract.

\section{Inhibition of lipid peroxidation capacity}

Inhibition of lipid peroxidation in the egg yolk of the hen was determined according to the procedure of Ohkawa et al. with modifications [23]. The egg yolk of hen $(0.5 \mathrm{~g})$ was emulsified with phosphate buffer $(0.1 \mathrm{M}, \mathrm{pH} 7.4)$ to achieve the final volume of $25 \mathrm{~g} / \mathrm{L}$. Then, $0.5 \mathrm{ml}$ of the egg homogenate was mixed with $0.1 \mathrm{ml}$ of each sample. The volume was made up to $1 \mathrm{ml}$ with distilled water. In this mixture $0.05 \mathrm{ml}$ ferrous sulfate $(0.07 \mathrm{M})$ was added and incubated for 30 minutes at room temperature to induce lipid peroxidation. After incubation, $1.5 \mathrm{ml}$ of acetic acid (20\%), $2 \mathrm{ml}$ of TBA (1\% w/v) in 1.1\% SDS, and $0.05 \mathrm{ml}$ TCA $(20 \%)$ was added and vortexed. This mixture was again incubated for 60 minutes in a boiling water bath. After cooling, $5.0 \mathrm{ml}$ of butanol was added and centrifuged at $3000 \mathrm{rpm}$ for 10 minutes. The organic upper layer was taken in a separate tube, and the absorbance was measured at $532 \mathrm{~nm}$. The inhibition of lipid peroxidation capacity was expressed as $\mathrm{IC}_{50}(\mu \mathrm{g} / \mathrm{ml})$. Catechin was used as the standard. The ability to inhibit lipid peroxidation was calculated by the following formula:

Inhibition of lipid peroxidation capacity $(\%)=\frac{A_{\text {control_}-} A_{\text {sample }}}{A_{\text {control }}} \times 100$

\section{Detection of antibacterial activity}

\section{Test organism}

Two Gram-positive, viz., Pseudomonas aeruginosa (MTCC 7093), Bacillus subtilis (MTCC 121), and Staphylococcus aureus (MTCC 7443), and four Gram-negative bacteria, viz., Pseudomonas aeruginosa (MTCC 7093), Escherichia coli (MTCC 729), Enterobacter aerogenes (MTCC 111), and Klebsiella pneumoniae (MTCC 661) were used. These test organisms were procured from the Department of Studies in Microbiology, University of Mysore, Karnataka, India.

\section{Antibacterial activity}

The inhibitory effect of the endophytic fungal extract was tested by paper disc diffusion method [24]. The crude extract of endophytic fungi was dissolved in dimethyl sulfoxide (DMSO) and tested on the Mueller-Hinton agar medium seeded with the test bacterium at $250 \mu \mathrm{g}$ per disc ( $5 \mathrm{~mm}$ diameter, Whatman No. 1) concentration. Streptomycin $(10 \mu \mathrm{g} / \mathrm{disc})$ was used as positive control and the paper disc loaded with only DMSO was negative control. The test plates were incubated for $24 \mathrm{hrs}$ at $35 \pm 2^{\circ} \mathrm{C}$, and the inhibition zone was measured. The test was done in three replicates.

Determination of minimal inhibitory concentration (MIC) and minimum bactericidal concentration (MBC)

The MIC was determined by the modified broth dilution method [25]. MIC test was done using sterile 96 well microplate (Tarsons, Kolkata, India). The wells were filled with the reaction mixture containing $90 \mu \mathrm{l}$ bacterial suspensions $\left(10^{6} \mathrm{CFU} / \mathrm{ml}\right)$ and $10 \mu \mathrm{l}$ of the test sample with different concentrations $(2 \mathrm{mg} / \mathrm{ml}$ to $0.02 \mathrm{mg} / \mathrm{ml}$ ). Culture medium with $1 \%$ DMSO was the negative control, and streptomycin sulfate $(0.4-0.01 \mathrm{mg} / \mathrm{ml})$ was the positive control. The microplates were incubated for $24 \mathrm{hrs}$ at $35 \pm 2^{\circ} \mathrm{C}$. After incubation, $10 \mu \mathrm{l}$ of indicator 3-[4,5-dimethyl-thiazol-2-yl]-2,5-diphenyltetrazolium bromide $(0.5 \mathrm{mg} / \mathrm{ml}$ phosphate buffer saline) was added to visualize the microbial growth. The lowest sample concentration at which no blue color appeared was determined as MIC. Wells containing MIC concentration and above were inoculated onto agar medium to check cell viability. The lowest concentration with no viable cells was determined as MBC. The test was done in three replicates.

\section{Data and statistical analysis}

The colonization frequency (CF) was calculated by the following formula:

$$
\% \mathrm{CF}=\frac{\mathrm{N}_{\mathrm{col}}}{\mathrm{N}_{\mathrm{t}}} \times 100
$$

Where, $\mathrm{N}_{\text {col }}$ is number of tissue segments colonized by a fungus; $\mathrm{N}_{\mathrm{t}}$ is the total number of tissue segments plated [26].

Data reported as mean \pm standard deviation of three independent replicates. Comparison among means was analyzed with one-way ANOVA and Tukey-Kramer multiple comparison tests using GraphPad InStat 3.0. Any two data were considered statistically significant at $\mathrm{p}<0.05$ and denoted with different superscripts.

\section{RESULTS}

Isolation and identification of fungal endophytes

Endophytic fungi were isolated from leaf and stem parts of J. wynaadensis. A total of 281 isolates distributed in nine endophytic species were recovered from 400 plant fragments. The isolates were identified with their spore morphology (Fig. 3) as well as by analyzing the DNA sequence of the ITS region. The identified strains with their Genbank accession numbers, isolation number and \%CF are depicted in Table 1. Results indicated that the stem part had more number of isolates (161) than leaves (120). The nine endophytic species belonged to six genera. Three different species of Fusarium and two 


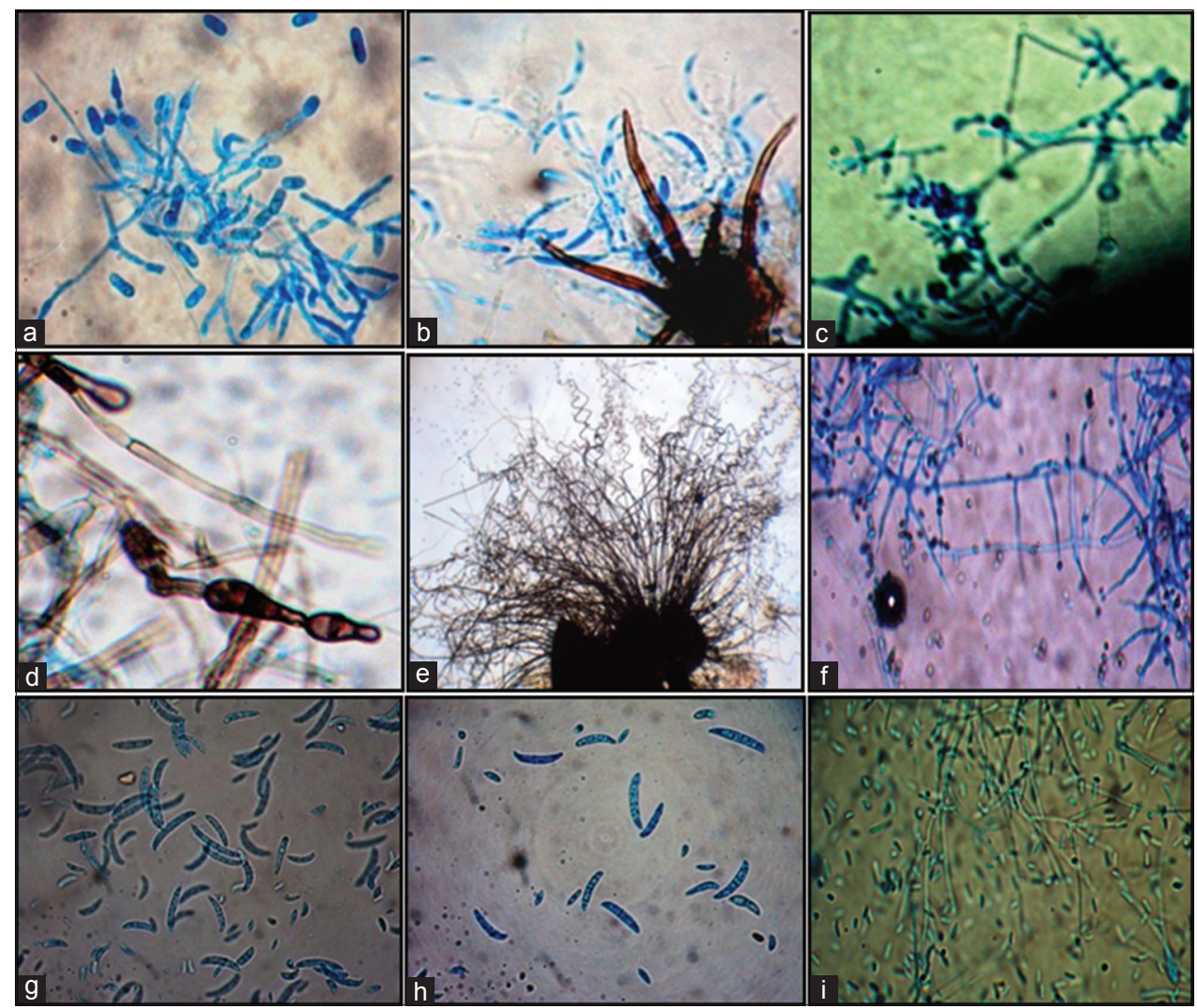

Fig. 3: Spore morphology of fungal endophytes isolated from plant fragments. (a) Colletotrichum lindemuthianum, (b) Colletotrichum truncatum, (c) Trichoderma harzianum, (d) Alternaria alternata, (e) Chaetomium globosum, (f) Sarocladium kiliense, (g) Fusarium incarnatum, (h) Fusarium oxysporum, and (i) Fusarium solani

Table 1: Taxonomic identification and percent \%CF of the fungal endophytes isolated from J. wynaadensis

\begin{tabular}{|c|c|c|c|c|c|c|c|}
\hline \multirow[t]{2}{*}{ Endophytic fungi } & \multirow[t]{2}{*}{ Code } & \multirow[t]{2}{*}{ Accession No. } & \multicolumn{2}{|c|}{ Leaf* } & \multicolumn{2}{|c|}{ Stem* } & \multirow[t]{2}{*}{ Total \%CF } \\
\hline & & & I & $\% \mathrm{CF}$ & I & $\% \mathrm{CF}$ & \\
\hline Fusarium incarnatum & JW-WG-01 & KY052769 & 5 & 2.5 & 19 & 9.5 & 6.0 \\
\hline Colletotrichum truncatum & JW-WG-03 & KY052773 & - & - & 33 & 16.5 & 8.3 \\
\hline Trichoderma harzianum & JW-WG-04 & KY072924 & 13 & 6.5 & - & - & 3.3 \\
\hline Colletotrichum lindemuthianum & JW-WG-05 & KY484535 & 27 & 13.5 & 31 & 15.5 & 13.8 \\
\hline Chaetomium globosum & JW-WG-06 & KY484536 & 18 & 9.0 & 25 & 12.5 & 10.8 \\
\hline Fusarium oxysporum & JW-WG-07 & KY484537 & 15 & 7.5 & 11 & 5.5 & 6.5 \\
\hline Fusarium solani & JW-WG-08 & KY484538 & 21 & 10.5 & 24 & 12.0 & 11.3 \\
\hline Alternaria alternata & JW-WG-09 & KY626175 & - & - & 18 & 9.0 & 4.5 \\
\hline
\end{tabular}

*200 fragments were plated from leaf and stem, respectively. I: Number of isolates, CF: Colonization frequency

of Colletotrichum were recovered. Colletotrichum lindemuthianum showed highest \%CF (13.8) followed by Fusarium solani (11.3) and Chaetomium globosum (10.8). The least \%CF was recorded for Trichoderma harzianum.

\section{Determination of TPC and flavonoid content}

The TPC of the extracts is represented in Fig. 4. TPC of the extracts ranged from $4.8 \pm 0.08$ to $20.74 \pm 0.96 \mathrm{mg} \mathrm{GAE} / \mathrm{g}$ dry extract. Fusarium incarnatum extracts showed highest TPC $(20.74 \pm 0.96 \mathrm{mg}$ GAE/g dry extract) followed by $T$. harzianum extracts $(13.83 \pm 0.26 \mathrm{GAE} / \mathrm{g}$ dry extract, respectively). F. solani exhibited least phenolic content (4.8 $\pm 0.08 \mathrm{mg} \mathrm{GAE} / \mathrm{g}$ dry extract).

Flavonoid was detected in four endophytic strains (Fig. 4). The TFC ranged from $2.1 \pm 0.08$ to $8.75 \pm 0.6 \mathrm{mg} \mathrm{CE} / \mathrm{g}$ dry extract. F. incarnatum exhibited high flavonoid content $(8.75 \pm 0.6 \mathrm{mg} \mathrm{CE} / \mathrm{g}$ dry extract), whereas, the lowest TFC was recorded for $C$. lindemuthianum.

\section{Antioxidant capacity}

ABTS $^{+}$radical scavenging assay

The total antioxidant capacity of endophytic extracts was determined by $\mathrm{ABTS}^{+}$scavenging capacity. The scavenging capacity of the extracts varied considerably, ranging from $6.2 \pm 0.3$ to $25.1 \pm 0.1 \mathrm{mg}$ TE/g dry extract (Table 2). Among the extracts, $F$. incarnatum showed high scavenging capacity followed by T. harzianum and Sarocladium kiliense $(17.5 \pm 0.2$ and $15.3 \pm 0.3 \mathrm{mg} \mathrm{TE} / \mathrm{g}$ dry extract, respectively) in consistence with the TPC.

\section{DPPH radical scavenging assay}

The DPPH radical is almost stable and used for antioxidant activity widely. The radical scavenging activity is presented as $50 \%$ scavenging activity $\left(\mathrm{IC}_{50}\right)$ in Table 2 . As depicted, the $\mathrm{IC}_{50}$ value of the fungal extracts varied considerably ( $379.98 \pm 0.8$ to $1920.67 \pm 134 \mu \mathrm{g} / \mathrm{ml})$. F incarnatum showed highest scavenging activity with $379.98 \pm 0.8 \mu \mathrm{g} / \mathrm{ml}$, followed by T. harzianum and S. kiliense. 


\section{Reducing power assay}

Antioxidant compounds have the reductive ability to transform $\mathrm{Fe}^{3+}$ to $\mathrm{Fe}^{2+}$ through their functional groups which are susceptible to electron transfer. The reducing power of ferric ion to ferrous ion by the fungal extracts is represented in terms of AA equivalent (Table 2). The values of reducing power assay ranged from $7.8 \pm 0.07$ to $38.3 \pm 0.6 \mathrm{mg} \mathrm{AA} / \mathrm{g}$ dry extract. $F$. incarnatum showed the highest activity $(38.3 \pm 0.6 \mathrm{mg} \mathrm{AA} / \mathrm{g}$ dry extract). The reducing power activity of $F$. solani was found to be the lowest.

\section{Inhibition of lipid peroxidation capacity}

The peroxidation reaction was induced with $\mathrm{Fe}^{++}$. The inhibition of lipid peroxidation capacity of fungal extracts is presented in Table 2. The capacity of the extracts ranged from $534.69 \pm 2.7 \mu \mathrm{g} / \mathrm{ml}$ to $1338.3 \pm 22.7 \mu \mathrm{g} / \mathrm{ml}$. The extract of $F$. incarnatum showed highest inhibition capacity $(534.69 \pm 2.7 \mu \mathrm{g} / \mathrm{ml})$ followed by $T$. harzianum $(931.42 \pm 8.2 \mu \mathrm{g} / \mathrm{ml})$. Alternaria alternata, C. lindemuthianum, and F. solani did not show any activity, whereas Colletotrichum truncatum and Fusarium oxysporum showed very little activity.

\section{Antibacterial activity}

The antibacterial activity of strains was tested against six pathogenic bacteria, and the area of inhibition zone is presented in Table 3. The strains were further tested for MIC and MBC. The results depicted in Table 4. F. incarnatum exhibited highest inhibition zone against all the pathogens except $B$. subtilis followed by $C$. lindemuthianum and C. truncatum. The inhibition zone formed by $F$. incarnatum is represented in Fig. 5. B. subtilis found to be resistant against all the extracts F. oxysporum did not show any activity. All endophytic fungal extracts

Table 2: Antioxidant capacity of fungal endophytes isolated from J. wynaadensis

\begin{tabular}{|c|c|c|c|c|}
\hline Fungal strains & $\begin{array}{l}\text { ABTS }^{+} \text {scavenging capacity } \\
\text { (mg TE/g dry extract) }\end{array}$ & $\begin{array}{l}\text { Reducing power } \\
\text { (mg AA/g dry extract) }\end{array}$ & $\begin{array}{l}\text { DPPH radical scavenging } \\
\text { capacity }\left(\mathrm{IC}_{50} \mu \mathrm{g} / \mathrm{ml}\right)\end{array}$ & $\begin{array}{l}\text { Inhibition of lipid } \\
\text { peroxidation capacity } \\
\left(\mathrm{IC}_{50} \mu \mathrm{g} / \mathrm{ml}\right)\end{array}$ \\
\hline Fusarium incarnatum & $25.1 \pm 0.1^{\mathrm{a}}$ & $38.3 \pm 0.6^{\mathrm{a}}$ & $379.98 \pm 0.8^{b}$ & $534.69 \pm 2.7^{b}$ \\
\hline Trichoderma harzianum & $17.5 \pm 0.2^{b}$ & $21.15 \pm 0.3^{b}$ & $543.67 \pm 16.6^{c}$ & $931.42 \pm 8.2^{c}$ \\
\hline Sarocladium kiliense & $15.3 \pm 0.3^{c}$ & $16.7 \pm 0.6^{c}$ & $792.15 \pm 28.5^{d}$ & $981.38 \pm 16.8^{\mathrm{d}}$ \\
\hline Chaetomium globosum & $12.9 \pm 0.1^{\mathrm{d}}$ & $15.24 \pm 0.3^{d}$ & $930.62 \pm 10.2^{\mathrm{e}}$ & $105084 \pm 3.1^{\mathrm{e}}$ \\
\hline Fusarium oxysporum & $11.8 \pm 0.3^{\mathrm{e}}$ & $14.3 \pm 0.1^{\mathrm{e}}$ & $1155.54 \pm 5.5^{f}$ & $1203.45 \pm 10.2^{\mathrm{f}}$ \\
\hline Alternaria alternata & $8.3 \pm 0.1^{\mathrm{g}}$ & $9.5 \pm 0.2^{\mathrm{g}}$ & $1328.18 \pm 32.4^{\mathrm{h}}$ & - \\
\hline Colletotrichum & $7.6 \pm 0.1^{\mathrm{h}}$ & $8.2 \pm 0.3^{\mathrm{h}}$ & $1541.74 \pm 77.3^{\mathrm{i}}$ & - \\
\hline \multicolumn{5}{|l|}{ lindemuthianum } \\
\hline \multirow[t]{2}{*}{ Fusarium solani } & $6.2 \pm 0.3^{\mathrm{i}}$ & $7.8 \pm 0.07^{\mathrm{h}}$ & $1920.67 \pm 134.0^{j}$ & - \\
\hline & & AA & $7.7 \pm 0.02^{\mathrm{a}}$ & $30.7 \pm 2.1^{\mathrm{a}}$ \\
\hline
\end{tabular}

Data are reported as mean \pm SD of three independent analyses $(n=3)$. Mean with the different superscript within a column are significantly different ( $<0.05)$ by one-way ANOVA test. AA: Ascorbic acid, ABTS': 2, 2'-azino-bis (3- ethylbenzthiazoline-6-sulphonic acid), TE: Trolox equivalent, DPPH: 1, 1-diphenyl-2- picrylhydrazyl, $\mathrm{IC}_{50}$ : Inhibitory concentration $50 \%$, J. wynaadensis: Justicia wynaadensis

Table 3: Antibacterial activity of fungal endophytes isolated from J. wynaadensis against six pathogenic bacteria

\begin{tabular}{|c|c|c|c|c|c|c|c|}
\hline Fungal strains extract & $\begin{array}{l}\text { Pseudomonas } \\
\text { aeruginosa }\end{array}$ & $\begin{array}{l}\text { Bacillus } \\
\text { subtilis }\end{array}$ & $\begin{array}{l}\text { Staphylococcus } \\
\text { aureus }\end{array}$ & $\begin{array}{l}\text { Escherichia } \\
\text { coli }\end{array}$ & $\begin{array}{l}\text { Enterobacter } \\
\text { aerogenes }\end{array}$ & $\begin{array}{l}\text { Klebsiella } \\
\text { pneumoniae }\end{array}$ & $\begin{array}{l}\text { Pseudomonas } \\
\text { aeruginosa }\end{array}$ \\
\hline Fusarium incarnatum & $15.0 \pm 0.9$ & - & $12.5 \pm 0.5$ & $16.9 \pm 0.2$ & $15.6 \pm 0.7$ & $10.0 \pm 0.1$ & $15.0 \pm 0.9$ \\
\hline Trichoderma harzianum & $9.2 \pm 0.2$ & - & - & $10.0 \pm 0.5$ & $11.5 \pm 0.1$ & - & $9.2 \pm 0.2$ \\
\hline Sarocladium kiliense & $9.0 \pm 0.6$ & - & $9.0 \pm 0.1$ & $10.8 \pm 0.3$ & $8.0 \pm 0.2$ & - & $9.0 \pm 0.6$ \\
\hline Chaetomium globosum & - & - & - & - & $8.0 \pm 0.5$ & - & \\
\hline Fusarium oxysporum & - & - & - & - & - & - & \\
\hline Colletotrichum truncatum & $9.0 \pm 0.1$ & - & $9.3 \pm 0.1$ & $10.3 \pm 0.2$ & $8.0 \pm 0.4$ & $7.5 \pm 0.4$ & $9.0 \pm 0.1$ \\
\hline Colletotrichum lindemuthianum & $10.5 \pm 0.5$ & - & $7.0 \pm 0.5$ & $11.0 \pm 0.1$ & $9.2 \pm 0.2$ & $8.5 \pm 0.2$ & $10.5 \pm 0.5$ \\
\hline Fusarium solani & - & - & - & $8.0 \pm 0.1$ & 10.5 & - & \\
\hline Streptomycin* & $33 \pm 0.3$ & $32 \pm 0.1$ & $31.5 \pm 0.5$ & $20 \pm 0.1$ & $22 \pm 0.1$ & $30 \pm 0.2$ & $33 \pm 0.3$ \\
\hline
\end{tabular}

Data are reported as mean \pm SD (in $\mathrm{mm}$ ) of three independent analyses ( $\mathrm{n}=3$ ). ${ }^{*}$ Streptomycin $10 \mu \mathrm{g}$ disc used. SD: Standard deviation, J. wynaadensis: Justicia wynaadensis

Table 4: MIC (mg/ml) and (MBC mg/ml) of fungal endophytes

\begin{tabular}{|c|c|c|c|c|c|c|c|c|c|c|c|c|}
\hline \multirow[t]{2}{*}{$\begin{array}{l}\text { Endophytic fungal strain } \\
\text { extract }\end{array}$} & \multicolumn{2}{|c|}{$\begin{array}{l}\text { Staphylococcus } \\
\text { aureus }\end{array}$} & \multicolumn{2}{|c|}{$\begin{array}{l}\text { Escherichia } \\
\text { coli }\end{array}$} & \multicolumn{2}{|c|}{$\begin{array}{l}\text { Enterobacter } \\
\text { aerogenes }\end{array}$} & \multicolumn{2}{|c|}{$\begin{array}{l}\text { Klebsiella } \\
\text { pneumoniae }\end{array}$} & \multicolumn{2}{|c|}{$\begin{array}{l}\text { Klebsiella } \\
\text { pneumoniae }\end{array}$} & \multicolumn{2}{|c|}{$\begin{array}{l}\text { Pseudomonas } \\
\text { aeruginosa }\end{array}$} \\
\hline & MIC & MBC & MIC & MBC & MIC & MBC & MIC & MBC & MIC & MBC & MIC & MBC \\
\hline Fusarium incarnatum & 0.2 & 0.4 & 0.16 & 0.18 & 0.18 & 0.2 & 0.18 & 0.2 & 0.6 & 0.8 & 0.6 & 0.8 \\
\hline Trichoderma harzianum & - & - & 0.8 & 1.0 & 1.0 & 1.2 & 0.8 & 1.0 & 1.8 & 2.0 & 1.8 & 2.0 \\
\hline Sarocladium kiliense & 1.2 & 1.4 & 1.0 & 1.2 & 1.2 & 1.2 & 1.6 & 1.8 & 0.18 & 0.2 & 0.18 & 0.2 \\
\hline Chaetomium globosum & - & - & 1.8 & 2 & 2 & - & 1.6 & 1.8 & - & - & - & - \\
\hline Fusarium oxysporum & - & - & - & - & - & - & - & - & - & - & - & - \\
\hline Colletotrichum truncatum & 1.4 & 1.6 & 1.0 & 1.2 & 1.4 & 1.6 & 1.4 & 1.6 & 1.8 & 2.0 & 1.8 & 2.0 \\
\hline Alternaria alternata & - & - & 0.8 & 1.0 & 1.4 & 1.4 & 1.6 & 1.8 & 1.2 & 1.4 & 1.2 & 1.4 \\
\hline Colletotrichum lindemuthianum & 1.8 & 2.0 & 0.8 & 1.0 & 0.6 & 0.8 & 0.8 & 1.0 & 1.2 & 1.4 & 1.2 & 1.4 \\
\hline Fusarium solani & - & - & 1.2 & 1.4 & 2.0 & - & 1.0 & 1.2 & - & - & - & - \\
\hline
\end{tabular}

MIC: Minimal inhibitory concentration, MBC: Minimum bactericidal concentration 


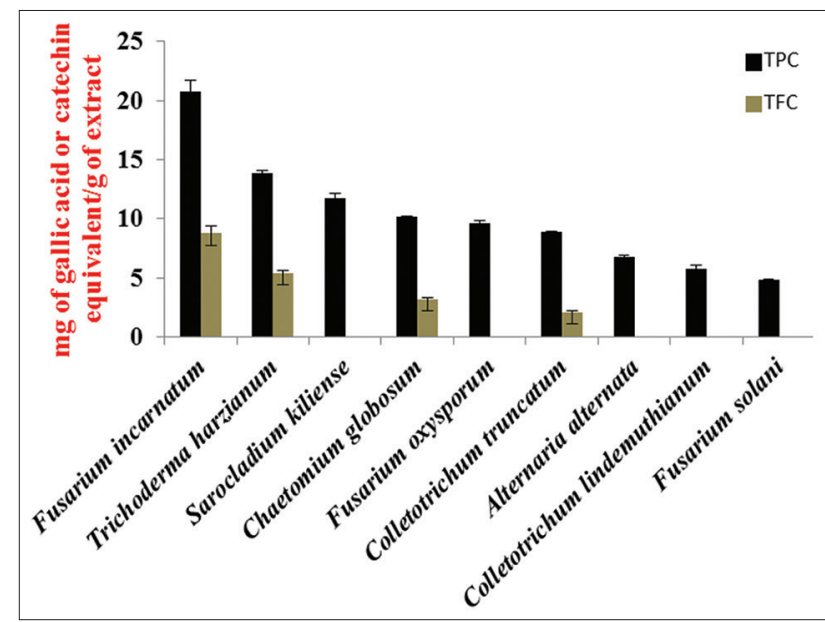

Fig. 4: Total phenolic content and total flavonoid content of fungal endophytes. Data are reported as mean \pm standard deviation of three independent analyses $(n=3)$

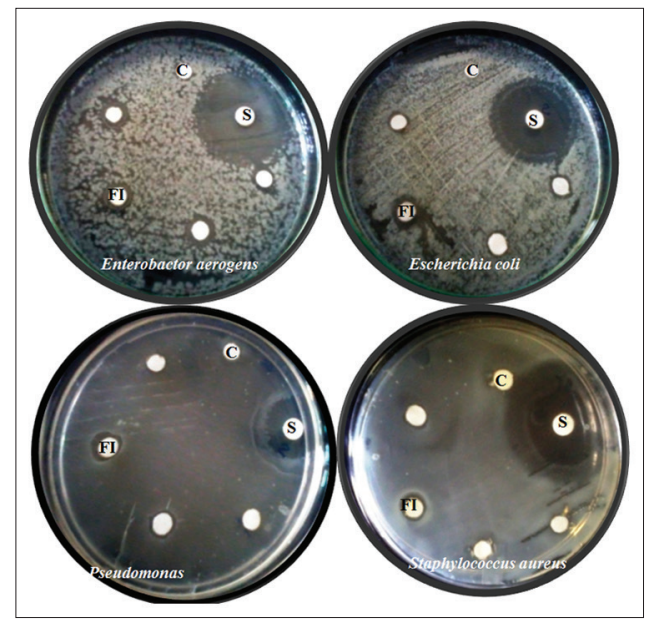

Fig. 5: Antibacterial zone formed by Fusarium incarnatum.

$S$ - Streptomycin disc (10 $\mu \mathrm{g} /$ disc), C - Negative control, FI - Fusarium incarnatum extract $(250 \mu \mathrm{g} / \mathrm{disc})$

showed inhibitory activity against $E$. coli between concentrations ranged from 2 to $0.16 \mathrm{mg} / \mathrm{ml}$ except $F$. oxysporum. C. globosum showed inhibition zone only against $E$. aerogenes.

\section{DISCUSSION}

Two regions in India have been recognized as the "biodiversity hotspot" viz., the Eastern Himalayas and the Western Ghats. Exceptional levels of plant endemism are observed in these regions which in turn attract researchers to unfold the treasure house of Mother Nature, causing irreparable damage to biodiversity. Therefore, interest is building on the study of endophytes as well as its secondary metabolites for bioprospecting. Many reports are present on the isolation of endophytes from the medicinal plants of the Western Ghats [11,26-28]. J. wynaadensis is one of the endemic and ethnomedicinally important plants of this region. To our knowledge, there are no reports on endophytic study of this plant. This study deals with the isolation of endophytic fungi and their bioactive potentials from J. wynaadensis. A total of nine endophytic fungal strains belonging to six genera, viz., Fusarium, Trichoderma, Sarocladium, Chaetomium, Colletotrichum, and Alternaria were identified. C. lindemuthianum showed highest \%CF (13.8). The genus Colletotrichum was previously isolated from different species of genus Justicia [29]. The isolates were identified morphologically (mycelial characters, spore morphology) as well as with the help of DNA sequence analysis of the ITS region. The isolates showed $95-100 \%$ similarity to their assigned taxa.

All nine strains were tested for the TPC, TFC, antioxidant, and antimicrobial capacities. The presence of phenolic and flavonoid phytochemicals in leaf and stem extracts of $J$. wynaadensis were reported by researchers $[30,31]$. The TPC of leaf and stem extracts $(0.65 \pm 0.08 \mathrm{mg}$ of GAE/g and $0.16 \pm 0.01 \mathrm{mg}$ of GAE/g, respectively) as was previously reported by Medapa et al. is found to be significantly lower than that of the endophytes isolated from this plant in this investigation $(4.8 \pm 0.08$ to $20.74 \pm 0.96 \mathrm{mg} \mathrm{GAE} / \mathrm{g}$ dry extract) [29]. The TFC is also found to be of significantly higher concentration than plant extract as reported by Medapa et al. [30]. However, our results of TPC and TFC of endophytes were significantly lower than the methanolic extract of $J$. wynaadensis leaf as reported by Abhishek et al. [31].

Among all the isolated strains, $F$ incarnatum was found to have potentially high antioxidant capacity. The DPPH radical scavenging capacity of leaf extract $\left(\mathrm{IC}_{50} 540.2485 \mu \mathrm{g} / \mathrm{ml}\right)$ of the plant was found to be lesser than the endophyte $F$. incarnatum $\left(\mathrm{IC}_{50} 379.98 \pm 0.8 \mu \mathrm{g} / \mathrm{ml}\right.$ ) [31]. $F$. incarnatum also displayed significant $\mathrm{ABTS}^{+}$radical scavenging (25.1 $\pm 0.1 \mathrm{mg} \mathrm{TE} / \mathrm{g}$ dry extract) and ferric reducing $(38.3 \pm 0.6 \mathrm{mg} \mathrm{AA} / \mathrm{g}$ dry extract) capacities. Hence, these findings encourage the exploration and bioprospecting of endophytic fungi.

In stressed condition, highly reactive $\mathrm{OH}^{-}$radical reacts with polyunsaturated fatty acids. Due to lipid peroxidation, various products such as malondialdeyde, 4-hydroxyl 2-nonenal, hydrocarbons, volatile ketones, and lipid polymers are produced which react with the cell macromolecules and effect cellular functions and biochemistry $[32,33]$. Therefore, the inhibition of lipid peroxidation is necessary for cell viability in stressed conditions. The extracts of $F$. incarnatum exhibited the highest activity $(534.69 \pm 2.7 \mu \mathrm{g} / \mathrm{ml})$ whereas, C. globosum, F. oxysporum, and $C$. truncatum showed significantly lower activity and A. alternata, C. lindemuthianum had no activity.

In this study, we have shown that the endophytes have broad spectrum antimicrobial activity among which $F$. incarnatum demonstrated the maximum activity. Although Colletotrichum spp. did not show antioxidative potentiality, they were found to show broad spectrum antimicrobial activity. Endophytic Colletotrichum sp. isolated from Prosopis juliflora also showed significant activity with a zone of inhibition against $E$. coli $(24.6 \pm 0.33)$ and $S$. aureus $(23.8 \pm 0.88)$ [34]. In consistent with this study Alternaria sp. isolated from medicinal plant Rauvolfia serpentina showed a zone of inhibition against $K$. pneumoniae $(17.6 \pm 0.58 \mathrm{~mm})$ and $E$. coli $(05.7 \pm 00.43 \mathrm{~mm})$ [35]. All the isolated strains except $F$. oxysporum formed inhibition zone against $E$. coli at $250 \mu \mathrm{g}$ concentrations. The endophytic Aspergillus sp. isolated from Justicia adhatoda has been reported to produce a stronger zone of inhibition against E. coli, Pseudomonas, and Klebsiella which corroborates our findings [36].

\section{CONCLUSION}

The Western Ghats of India is a biodiversity hotspot and a tropical rain forest. This place has a wealth of many medicinal plants which are not fully explored, for the presence of fungal endophytes. This study reported the occurrence of endophytic fungi from J. wynaadensis. To the best of our knowledge this is the first attempt to explore the treasure of endophytes and their bioactive potentiality from this plant. The strain F. incarnatum displayed broad spectrum antibacterial properties against Gram-positive and Gram-negative pathogens as well as significant antioxidative capacities. The strain T. harzianum displayed significant antiradical and ferric reducing capacities, and both species of Colletotrichum proved as potential antimicrobial agents. Hence, our findings encourage the exploration of these fungi and exploit them in search of potential drug discovery. 


\section{ACKNOWLEDGMENT}

The University Grant Commission-Major Research Project is thankfully acknowledged.

\section{REFERENCES}

1. Balick MJ, Elisabetsky E, Laind SA. editors. Medicinal Resources of the Tropical Forest: Biodiversity and its Importance for Human Health. NewYork: Columbia University Press; 1996.

2. Strobel G, Daisy B. Bioprospecting for microbial endophytes and their natural products. Microbiol Mol Biol Rev 2003;67(4):491-502.

3. Bacon CW, White JF. Microbial Endophytes. NewYork: Marcel Dekker; 2000. p. 341-88.

4. Owen NL, Hundley N. Endophytes - The chemical synthesizers inside plants. Sci Prog 2004;87:79-99.

5. Strobel GA. Endophytes as sources of bioactive products. Microbes Infect 2003;5(6):535-44.

6. Strobel G, Daisy B, Castillo U, Harper J. Natural products from endophytic microorganisms. J Nat Prod 2004;67(2):257-68.

7. Tan RX, Zou WX. Endophytes: A rich source of functional metabolites. Nat Prod Rep 2001;18(4):448-59.

8. Gunatilaka AA. Natural products from plant-associated microorganisms: Distribution, structural diversity, bioactivity, and implications of their occurrence. J Nat Prod 2006;69(3):509-26.

9. Huang WY, Cai YZ, Xing J, Corke H, Sun M. A potential antioxidant resource: Endophytic fungi from medicinal plants. Econ Bot 2007;61:14-30.

10. Karmakar R, Sunil K, Prakash HS. Antioxidant, anti-inflammatory, antimicrobial and cytotoxic properties of fungal endophytes from Garcinia species. Int J Pharm Pharm Sci 2013;5(3):889-97.

11. Das M, Nalini MS, Prakash HS. Antioxidative properties of phenolic compounds isolated from the fungal endophytes of Zingiber nimmonii (J. Graham) Dalzell. Front Biol 2017. DOI: 10.1007/s11515-0161441-z.

12. Gamble JS. Flora of the Presidency of Madras. Vol. II. London: Adlard and Sons Ltd.; 1967. p. 755-6.

13. Awan AJ, Ahmed CB, Uzair M, Aslam MS, Farooq U, Ishfaq K. Family acanthaceae and genus Aphelandra: Ethnopharmacological and phytochemical review. Int J Pharm Pharm Sci 2014;6(10):44-55.

14. Lingaraju, DP, Sudarshana MS, Rajashekar N. Ethnopharmacological survey of traditional medicinal plants in tribal areas of Kodagu district, Karnataka, India. J Pharm Res 2013;6:284-97.

15. Subbiah MT, Norman EJ. Rain forest plant extract with cellular cholesterol lowering properties. U S Pat 2002;6:365-411.

16. Tejesvi MV, Mahesh B, Nalini MS, Prakash HS, Kini KR, Subbiah V, et al. Endophytic fungal assemblages from the inner bark and twig of Terminalia arjuna W. and A. (Combretaceae). World J Microbiol Biotechnol 2005;21:1535-40.

17. Schulz B, Guske S, Dammann U, Boyle C. Endophyte host interactions II. Defining symbiosis of the endophyte host interaction. Symbiosis 1998;25:213-27.

18. Ausubel FM, Brent R, Kingston RE, Moore DD, Seidman JG, Smith JA, et al. Current protocols in molecular biology. New York: Wiley; 1994.
19. Liu X, Dong M, Chen X, Jiang M, Lv X, Yan G. Antioxidant activity and phenolics of an endophytic Xylaria sp. from Ginkgo biloba. Food Chem 2007; 105:548-54.

20. Barros L, Ferreira MJ, Queirós B, Ferreira CF, Baptista P. Total phenols, ascorbic acid, $\beta$-carotene and lycopene in Portuguese wild edible mushrooms and their antioxidant activities. Food Chem 2007;103:413-9

21. Re R, Pellegrini N, Proteggente A, Pannala A, Yang M, Evans CR. Antioxidant activity applying and improved ABTS radical cation decolorization assay. Free Radic Biol Med 1999;26:1231-7.

22. Oyaizu M. Studies on product of browning reaction prepared from glucose amine. J Nutr 1986;44:307-15.

23. Ohkawa H, Ohishi N, Yagi K. Assay for lipid peroxides in animal tissues by thiobarbituric acid reaction. Anal Biochem 1979;95(2):351-8.

24. Bauer AW, Kirby WM, Sherries JC, Turck M. Antibiotics susceptibility testing by the standardized single disc method. Am J ClinPathol 1966;45:493-6.

25. Xu L, Zhou L, Li J, Li X, Wang J. Fungal endophytes from Dioscorea zingiberensis and their antimicrobial activity. Lett Appl Microbiol 2008;46:68-72.

26. Nalini MS, Sunayana N, Prakash HS. Endophytic fungal diversity in medicinal plants of Western Ghats, India. Int J Biodiv 2014. DOI: $10.1155 / 2014 / 494213$

27. Akshatha VJ, Nalini MS, D'Souza C, Prakash HS. Streptomycete endophytes from anti-diabetic medicinal plants of the Western Ghats inhibit alpha-amylase and promote glucose uptake. Lett Appl Microbiol 2014;58:433-9.

28. Samaga PV, Rai VR. Diversity and bioactive potential of endophytic fungi from Nothapodytes foetida, Hypericum mysorense and Hypericum japonicum collected from Western Ghats of India. Ann Microbiol 2016;66:229-44

29. Gangadevi V, Muthumary J. Isolation of Colletotrichum gloeosporioides, a novel endophytic taxol-producing fungus from the leaves of a medicinal plant, Justicia gendarussa. Mycol Balc 2008;5:1-4.

30. Medapa S, Singh GR, Ravikumar V. The phytochemical and antioxidant screening of Justicia wynaadensis. Afr J Plant Sci 2011;5(9):489-92.

31. Abhishek M, Jain K, Somashekaraiah BV, Raman DN. Phytochemical composition and in-vitro antioxidant activity of Justicia wynaadensis leaves. IJIRSET 2015;4(9):8236-42.

32. Tuma DJ, Casey CA. Dangerous byproducts of alcohol breakdownfocus on adducts. Alcohol Res Health 2003;27:285-90.

33. Onyema OO, Farombi EO, Emerole GO, Ukoha AI, Onyeze GO. Effect of vitamin $\mathrm{E}$ on monosodium glutamate induced hepatotoxicity and oxidative stress in rats. Indian J Biochem Biophys 2006;43(1):20-4.

34. Srivastava A, Raveesha KA. Antimicrobial potential of fungal endophytes isolated from leaves of Prosopis juliflora (sw.) Dc. an important weed. Int J Pharm Pharm Sci 2015;7(12):128-36.

35. Sahu R, Kumar S, Aharwal RP, Sandhu SS. Antibacterial activity of isolated endophytic fungi from Rauvolfia serpentina (L.) Benth. Ex kurz. Int J Pharm Pharm Sci 2016;8(11):38-42.

36. Prabavathy D, Nachiyar CV. Study on the antimicrobial activity of Aspergillus sp isolated from Justicia adathoda. Indian J Sci Technol 2012;5(9):3317-20. 